\title{
Epidemiological Study of Patients with Spinal Cord Injury Treated in POLEM, a Specialized Clinic in São Paulo State - Brazil
}

\section{Estudo epidemiológico de pacientes com lesão medular tratados na POLEM, clínica especializada no estado de São Paulo - Brasil}

José Eduardo de Andrade Lopes ${ }^{1}$ Karl Alex Patteis dos Santos ${ }^{10}$ Caroline da Costa Machado ${ }^{10}$ Meire Cristina Borges ${ }^{1}{ }^{(0)}$ Eder Ferreira Coelho ${ }^{10}$ İris Lino Kemp Simões ${ }^{1(0)}$ Ivone Mara Pereira ${ }^{1(1)}$ Mariele Torricelli Brunelli Dalera1® ${ }^{10}$ Talita Schneider de Camargo Bertazini ${ }^{1}$ José Eduardo de Andrade Lopes ${ }^{10}$

1 POLEM - Associação de Apoio às Pessoas com Lesão Medular, São Paulo, SP, Brazil

Arq Bras Neurocir 2021;40(2):e125-e129.
Address for correspondence José Eduardo de Andrade Lopes, Rua Domingos Sínico, 334, Jardim Guaçu-Mirim, Mogi Guaçu, SP, 138433320, Brazil (e-mail: joseitalopes2@gmail.com).

\section{Abstract \\ Keywords \\ - spinal cord injury \\ - epidemiology \\ - causes \\ - rehabilitation}

\section{Resumo}

Objective To analyze the epidemiological profile of patients with spinal cord injury treated at POLEM - Associação de Apoio às Pessoas com Lesão Medular (Association for Supporting People with Spinal Cord Injury).

Method The population studied comprised 113 patients with spinal cord injury, of traumatic or nontraumatic etiology, and the data obtained were compared with those of other institutions.

Results Of the 113 patients, $70.8 \%$ were male and $29.2 \%$ female. Traumatic lesions were responsible for $54 \%$ of the patients, and nontraumatic for $46 \%$. Of the patients with traumatic injury, $90.2 \%$ were male, the main cause being traffic accidents. In nontraumatic lesions, women were the most affected, 51.9\%; and dysraphism and myelitis were the main causes ( $31 \%$ and $21 \%$, respectively).

Conclusion The results showed an important incidence of spinal cord injury due to trauma, mainly affecting young individuals of productive age and low educational level, representing high economic and social costs. The data found in the present study are similar to those of other studies performed in our country.

Objetivos Analisar o perfil epidemiológico dos pacientes com lesão medular atendidos na POLEM - Associação de Apoio às Pessoas com Lesão Medular.

Método A população estudada compreendeu 113 pacientes com lesão medular, de etiologia traumática ou não, e os dados obtidos foram comparados com os de outras instituições. received

March 19, 2020

accepted

September 4, 2020

published online

February 15, 2021
DOI https://doi.org/ 10.1055/s-0040-1719009. ISSN 0103-5355. (c) 2021. Sociedade Brasileira de Neurocirurgia. All rights reserved. This is an open access article published by Thieme under the terms of the Creative Commons Attribution-NonDerivative-NonCommercial-License, permitting copying and reproduction so long as the original work is given appropriate credit. Contents may not be used for commercial purposes, or adapted, remixed, transformed or built upon. (https://creativecommons.org/ licenses/by-nc-nd/4.0/)

Thieme Revinter Publicações Ltda., Rua do Matoso 170, Rio de Janeiro, RJ, CEP 20270-135, Brazil 
Resultados Dos 113 pacientes, 70,8\% eram do sexo masculino e $29,2 \%$ do sexo feminino. As lesões traumáticas foram responsáveis por $54 \%$ dos pacientes, e as não traumáticas por $46 \%$. Dos pacientes com lesão traumática, $90,2 \%$ eram do sexo masculino, sendo a principal causa os acidentes de trânsito. Nas lesões não traumáticas, as mulheres foram as mais acometidas, 51,9\%; e o disrafismo e as mielites foram as principais causas ( $31 \%$ e $21 \%$, respectivamente).

Palavras-chave

- lesão medular

- epidemiologia

- causas

- reabilitacão
Conclusão Pelos dados obtidos, mostrou-se a incidência importante de lesão medular por trauma, acometendo principalmente indivíduos jovens, em idade produtiva e com baixo nível de escolaridade, representando elevados custos econômico e social. Os dados encontrados no presente estudo são semelhantes a outros realizados em nosso país.

\section{Introduction}

Spinal cord injury (SCI) is one of the most devastating lesions that can compromise people's health. Besides physical incapacity, it causes serious psychological, financial and social losses.

As an aggravating factor, care with people with spinal cord injury, in addition to treatment in the acute phase, requires continuous multidisciplinary care, without which the patient will not be better recovered. All this entails enormous expenses. In Canada, according to Krueger et al., the lifetime treatment cost of a person with incomplete paraplegia is around CAD $\$ 1.47$ million, while for a person with complete quadriplegia the cost is around CAD \$ 3.03 million. This estimate includes the costs of the various complications that occur. The annual expense for treating people with spinal cord injury in Canada reaches CAD \$ 2.67 billion. $^{1}$ Most studies show a high male/female ratio, especially in traumatic lesions, with a high incidence in young individuals, 30 years old. Traffic accidents are the main etiological agent. ${ }^{1}$

We try to show the causes of spinal cord injury and its level, stratified according to gender, age when the injury occurred, time elapsed between the onset of illness and the start of treatment, socioeconomic situation, nutritional status of the patients, function of the bladder and bowel.

Studies on the epidemiology of spinal cord injury in Brazil and even in South America are rare. ${ }^{2,3}$ Data on the prevalence and treatment costs are also uncertain. With the present study, we try to show the main causes and nuances of this disease in our association and make a comparison with other works performed both in Brazil and in other countries.

It is intended mainly, together with other published works, to provide subsidies for the establishment of strategies for prevention and treatment, reducing the suffering of people and expenses arising from this serious illness.

\section{Methods}

The records of 113 patients suitable for the start of rehabilitation activities at POLEM were analyzed and reviewed. All of the patients had a clinical diagnosis of spinal cord injury. The data that will be included in the present study were obtained from clinical records, both from active patients still in the process of rehabilitation, and from patients who no longer participate in the activities in the association.

The charts analyzed include the initial evaluations of the therapeutic segments, and the anamneses of the physiotherapy, neurology, occupational therapy, nutrition, psychology (patient and caregiver), nursing, and social services sectors were reviewed.

The variables analyzed in the present study were: gender, types of injury (traumatic or nontraumatic), etiology and level of injury, age when injured, age at the start of rehabilitation, time interval between the onset of lesions and early rehabilitation, schooling, marital status, whether or not they have any type of health plan, use of assistive technology, receipt of benefits, caregivers, body mass index (BMI), bowel functioning and bladder catheterization.

The collected data was typed in spreadsheets of the Microsoft Excel application in Windows 7 (Microsoft Corporation, Redmond, WA, USA), in the form of double entry for the verification of typos. The descriptive analysis was performed and presented in absolute and relative frequency distribution tables (percentage).

\section{Results}

Out of the total number of 113 assisted patients, 80 (70.8\%) were male and $33(29.2 \%)$ were female, a ratio of $2.42: 1$. Of these, 61 (54\%) suffered traumatic injuries and 52 (46\%) had nontraumatic lesions, with a ratio of 1.17:1.

Among the traumatic lesions, 55 (90.2\%) of the patients were male and 6 (9.8\%) were female, the ratio was 9.16:1.

In the nontraumatic lesions, unlike the traumatic lesions, the predominance was female, 27 (51.9\%), while in males there were $25(48,1 \%)$, ratio $1.08: 1$.

Among the traumatic injuries, traffic accident stood out with 33 patients, 15 by car accident, 13 by motorcycle accident, and 5 by trampling. In traffic accidents, 7 patients had between 11 and 20 years old, 4 male and 3 female. In the age group of 21 to 40 years old, there were 30 men and no women. Between 41 and 60 years old, there were 3 male patients and no female patients. Among the traumatic injuries, the injuries due to fall of height, injury by firearm projectile, diving in shallow water and trauma by load should be highlighted. See - Table 1. 
Table 1 Traumatic Etiology

\begin{tabular}{|l|l|l|}
\hline Traumatic Etiology & Absolute number & $\%$ \\
\hline Automobile accident & 15 & 25 \\
\hline Motorcycle accident & 13 & 21 \\
\hline Fall of height & 11 & 18 \\
\hline Firearm Injury (FAI) & 8 & 13 \\
\hline Trampling by car & 5 & 8 \\
\hline Trauma by load & 6 & 10 \\
\hline Shallow water diving & 3 & 5 \\
\hline Total & 61 & 100 \\
\hline
\end{tabular}

Table 2 Nontraumatic Etiology

\begin{tabular}{|l|l|l|}
\hline Nontraumatic Etiology & Absolute number & $\%$ \\
\hline Spinal cord Disraphism & 16 & 31 \\
\hline Myelitis & 11 & 21 \\
\hline Tumoral & 10 & 19 \\
\hline $\begin{array}{l}\text { Cervical spondylotic } \\
\text { myelopathy }\end{array}$ & 4 & 8 \\
\hline Vascular disease & 3 & 6 \\
\hline Amyotrophic lateral sclerosis & 2 & 4 \\
\hline Multiple sclerosis & 2 & 4 \\
\hline Siyringomyelia & 2 & 4 \\
\hline Could not report & 2 & 4 \\
\hline Total & 52 & 100 \\
\hline
\end{tabular}

Among nontraumatic lesions, dysraphism is the main cause, followed by myelitis. See - Table 2 .

Regarding the level of the lesion, the thoracic region was the most affected, followed by the cervical region and finally the lumbar region. See - Table 3

The mean age for incidence of the lesion (traumatic or nontraumatic) was 38 years and 3 months old, ranging from 1 day old (congenital lesion) to 75 years old. The time interval between the incidence of the lesion and the beginning of rehabilitation in the association was 6 years and 5 months, ranging from 1 month old to 43 years and 3 months old.

Regarding marital status, 47 individuals (4 1.6\%) were married and 45 (39.8\%) were single. Widows accounted for 6 (5.3\%), divorced for $7,(6,2 \%)$ and 8 (7.0\%) lived in a stable union.

Of those assisted, 42 (37.2\%) had health care plans and 61 (53.9\%) were users of the Brazilian Unified Health System (SUS, in the Portuguese acronym). In 10 charts we did not find such information.

Among the beneficiaries, 107 (94.7\%) used one or more types of assistive technology, and the most common were: wheelchair, shower chair, long tutors with pelvic belt, special mattress and others. See - Table 5.

Out of the patients treated, 40 (35.3\%) were in retirement, 27 (23.9\%) were sick, and 13 (11.5\%) were under Continuous
Table 3 Injury Level

\begin{tabular}{|l|l|l|}
\hline Injury Level & Absolute number & $\%$ \\
\hline Thoracic & 57 & 50 \\
\hline Cervical & 37 & 33 \\
\hline Low back & 19 & 17 \\
\hline Total & 113 & 100 \\
\hline
\end{tabular}

Table 4 Level of schooling

\begin{tabular}{|l|l|l|}
\hline Level of schooling & $\begin{array}{l}\text { Absolute } \\
\text { number }\end{array}$ & $\%$ \\
\hline Did not complete elementary school & 54 & 47.7 \\
\hline Completed high school & 28 & 24.7 \\
\hline Completed higher education & 7 & 6.2 \\
\hline Did not complete high school & 6 & 5.3 \\
\hline Completed elementary school & 5 & 4.4 \\
\hline Attended nursery school & 3 & 2.7 \\
\hline Illiterate & 3 & 2.7 \\
\hline Attended technical education & 2 & 1.8 \\
\hline Not old enough to attend school & 2 & 1.8 \\
\hline Did not complete higher education & 1 & 0.9 \\
\hline Attended special education & 1 & 0.9 \\
\hline No information found & 1 & 0.9 \\
\hline Total & 113 & 100 \\
\hline
\end{tabular}

Table 5 Type of assistive technology

\begin{tabular}{|l|l|l|}
\hline Type of technology & Absolute number & $\%$ \\
\hline Wheelchair & 90 & 80 \\
\hline Shower chair & 52 & 46 \\
\hline Tutor long with pelvic belt & 9 & 8 \\
\hline Gutters & 21 & 19 \\
\hline Walker & 13 & 11 \\
\hline Egg Box Mattress & 14 & 12 \\
\hline Others * & 46 & 41 \\
\hline
\end{tabular}

* others: long tutor without pelvic belt (1 patient), board transfer, ${ }^{2}$ bracing for shaving, ${ }^{1}$ bracing for the computer, ${ }^{1}$ hand orthosis, ${ }^{4}$ splint to handle ${ }^{4}$ abdominal strap, ${ }^{1}$ compression stocking, ${ }^{4}$ positioning roller, ${ }^{1}$ cervical collar, ${ }^{1}$ Putti vest, ${ }^{1}$ Canadian crutches ${ }^{5}$ axillary crutches, ${ }^{1}$ common cane, ${ }^{2} 4$-point cane, ${ }^{2}$ water mattress, ${ }^{2}$ air mattress, ${ }^{3}$ hospital bed, ${ }^{7}$ water seat, ${ }^{4}$ air seat, ${ }^{3}$ gel seat, ${ }^{1}$ vehicular adaptation. ${ }^{1}$

Benefit Payment (BPC, in the Portuguese acronym). In 33 records, there was no reference to the receipt of benefits.

In the charts analyzed, 98 patients (86.7\%) received caregiver assistance and $10(8.8 \%)$ did not receive it, and in 5 (4.4\%) medical records no information was found in this regard.

Bladder emptying data show that 20 patients (17.7\%) had urinary incontinence, 48 (42.5\%) had intermittent clear 
catheterization, 38 (33.6\%) had spontaneous urination, 2 (1.8\%) underwent cystostomy, and in 5 medical records (4.4\%) we did not obtain data.

Regarding nutritional status, of the 113 patients evaluated, 30 (26.5\%) were eutrophic, 21 (18.6\%) were preobese or overweight. The same number of 5 patients (4.4\%) for grade III and grade I low weight was found. There were 3 patients with grade II low weight (2.7\%).

The variables for classification of BMI were: grade I obesity, 7 patients (6.2\%), grade II, 2 patients (1.8\%), grade III, 1 patient $(0.9 \%)$. In 39 (34.5\%) of the patients, the BMI was not evaluated.

Regarding intestinal function, it was found that 30 (26.5\%) had constipation and that $60(53.1 \%)$ didn't, and 23 patients (20.4\%) were not evaluated.

\section{Discussion}

In the present study, the data show a significant prevalence of spinal cord injury in men, which is in agreement with data found globally. ${ }^{2}$ This number is due to the high incidence of trauma as a cause in males. Of note among the traumatic causes are traffic accidents as the main responsible for SCI, and the main site of injury is the thoracic spine, followed by the cervical spine.

In the literature found in national journals, however, there is divergence in the data, some differing mainly in the cause and location of the trauma.

An epidemiological study performed at the Lar Escola São Francisco, in the city of São Paulo, state of São Paulo, Brazil, with 171 patients seen from 1999 to 2001, showed that 107 (62.6\%) were male and 64 (37.4\%) were female. The mean age of those attended was 35.4 years old, ranging from 1 to 78 years old. These data are similar to those found in the present study. There was a discrepancy in the causes, because in $53(30.1 \%)$ it was due to firearm injury (FAI), 30 (17.5\%) due to falls, 23 (13.4\%) due to tumor, and 15 (8.8\%) due to traffic accident. ${ }^{3}$

Work done by Botelho et al. at the Hospital Mandaqui in São Paulo, where 95 patients with medullar spinal trauma were attended, 82 (86.3\%) were male and 13 (13.7\%) were female, a ratio of $6.3: 1$, numbers close to those shown in the present study. Regarding the etiology, the main ones were: falls, 31 patients (32.6\%), automotive accident $(n=22 ; 23 \%)$, dive in shallow water $(n=14 ; 14.7 \%)$, and FAI $(5.2 \%) .{ }^{4}$ These data are different from those found in POLEM.

In the Physiotherapy Outpatient Clinic of the Universidade de Ciências Médicas da Paraíba, a survey of 59 patients showed that 55 (93.22\%) were male and 6 (6.77\%) were female. The mean age was 34 years old and the thoracic segment was the most affected ( $n=30 ; 50.84 \%)$, followed by the cervical segment $(n=24 ; 40.67 \%)$ and by the lumbar segment ( $n=5 ; 8.47 \%$ ). Among the causes, FAI was the main one, with 27 patients (45.76\%), followed by car accident, with $12(20.33 \%)$ patients. ${ }^{5}$ In the Disability Service Center (DAC, in the Portuguese acronym) of the Universidade de Passo Fundo, out of the 49 patients attended, 40 (81.6\%) were male and $9(18.4 \%)$ were female. The thoracic level was the most affected (77.5\%), and the main causes were falls (36.7\%), traffic accidents (32.7\%) and FAIs (24.5\%). ${ }^{6}$

In the masters dissertation of Noronha, in June 2008, she evaluated 156 patients with spinal cord injury. The main causes were 37 patients (23.7\%), 32 due to FAI (20.5\%), and 31 due to car accident (19.9\%). There was a predominance of lesions in the thoracic level (45.8\%), followed by the cervical level (43.2\%). ${ }^{7}$

Another study, performed by Brito et al., comprised 87 patients, $71(81.6 \%)$ male and $16(18.4 \%)$ female, with a mean age of 33.9 years old. The most affected level was the thoracic, with 33 patients (37.9\%), followed by the cervical, with 23 patients (26.4\%), numbers close to those shown in the present study. Regarding the etiology, falls occurred in 37 patients (42.6\%), followed by car accident in 21 (24.2\%), motorcycle accident in 15 (17.2\%) and FAI in 11 (12.6\%). ${ }^{8}$

A study performed at the Neurological Physiotherapy Outpatient Clinic of the Hospital Universitário Regional do Norte do Paraná, with 25 patients with complete SCI, showed that 20 (80\%) were male and 5 (20\%) were female, with a mean age of 34, 6 years old. Regarding the etiology, $50 \%$ were victims of car accident, $20.8 \%$ were victims of FAI, $12.5 \%$ were whitewash and $8.3 \%$ were due to surgical procedures.

Custódio et al., in a retrospective survey with a sample of 208 patients, showed that $164(78.85 \%)$ were male and 44 (25.15\%) were female. Traffic accidents corresponded to $44.70 \%$ of the cases, motorcycle accidents to 56 patients (26.92\%), automobile accident to 37 patients (17.78\%), FAI to 30 patients (14.42\%), fall to $13.94 \%$, tumor to $7.69 \%$, diving in shallow water to $5.76 \%$, myelopathy due to stenosis to $2.88 \%$ and myelitis to $3.36 \%$. The most affected level was the thoracic (54.8\%), followed by the cervical (35.1\%) and the lumbar $(10.1 \%){ }^{10}$

In underdeveloped or developing countries, the percentage of SCI due to traumatic causes, mainly due to traffic accidents, is considerably high. In developed countries, this index has fallen, and the number of people with nontraumatic SCI has increased. But, even in these countries, there are disparate numbers. In Ontario, Canada, the main cause of traumatic SCI is fall from height. And in the states of Alabama and Mississippi, USA, the injury by violence is the main cause. Sports and recreational injury is the leading cause in the British Columbia, Canada (17.9\%), in Utah (15.7\%), USA, being the lowest in Mississippi (3.5\%).

Among the nontraumatic causes, there is also a great variation in the data found. In the present study, dysraphism and myelitis are the main causes, being that dysraphism showed a superior number to the ones found in the international studies.

It was also observed in the present study that the mean age for the incidence of the lesion was 35 years and 3 months old, and the time interval between the beginning of the SCI and the start of the rehabilitation center suitable 6 years 5 months, which is compatible with data found in other studies conducted in Brazil. ${ }^{3,7,10}$

Another important fact is the low level of schooling among the patients, coinciding with data from the Brazilian 
Institute of Geography and Statistics (IBGE, in the Portuguese acronym) Demographic Census, conducted in 2010, which indicates that there are 45.6 million Brazilians with at least 1 type of disability. Out of this total, $6.7 \%$ have complete higher education and $61 \%$ have no education or incomplete fundamental level.

Among nontraumatic causes, there is also great variation in statistics. In a study conducted in Okayama, Japan, the incidence of nontraumatic spinal cord injury is 20 per 1 million people and degenerative spinal disease accounts for $59 \%$ of the cases. Tumors account for $19 \%$ of the cases. ${ }^{2}$

In South Asia, only India has epidemiological data in three studies on the causes of SCI. High rates of bone-marrow tuberculosis were found in Bangalore (26\%), Karnataka (25\%) and Kashmir (38\%). But tumors also have a high incidence, $29 \%$ in Bangalore and 27\% in Karnataka. ${ }^{2}$

In Western Europe, data from 8 countries are reported: Denmark, France, Germany, Israel, Italy, The Netherlands, Scotland and Spain. The median incidence of nontraumatic spinal cord injury was 6 per 1 million people per year. We found high tumor rates (25\%) and degenerative spine disease (32\%) on average. Dysraphism was found in $5 \%$ in Spain and Italy and in 2\% in Denmark. Myelitis was the cause in $7 \%$ of the cases in Israel, 14\% in Denmark, and 23\% in Italy. ${ }^{2}$

In Turkey, studies in Ankara showed that tumors (29\%) and degenerative diseases of the spine $(29 \%)$ were the main causes. In Istanbul, tumors and degenerative diseases of the spine were responsible for $22 \%$ and $25 \%$, respectively. Inflammatory diseases were responsible for $23 \%$ of the cases in Ankara and of $20 \%$ in Istanbul. Dysraphism was the cause in $6 \%$ of the cases.

In the USA, a retrospective 5-year study points to spinal stenosis and tumors as the main causes of SCI, with $54 \%$ and $26 \%$, respectively. Myelitis accounted for $5 \%$ of patients treated. ${ }^{11}$ See table 4.

\section{Conclusion}

It was demonstrated in the present study that trauma represents the main cause of $\mathrm{SCI}$ affecting patients treated by POLEM, with the thoracic spine being the most affected. Out of the population studied, the highest incidence occurs in the young population, in working age, with a large majority of families with low educational level, representing a high economic and social cost. Based on the present study and on several others, preventive measures should be traced to decrease the incidence of this disease, which is a real tragedy.

\section{Authors' Contributions}

To perform this work, all authors contributed to the data collection and their individualization in the area of action, literature, discussion, review, approval and drafting the final version of the results. Lopes J. E. A.: article intellectual concept and study design; Simões I. L. K.: confection of graphics and tables, typing.

\section{Conflict of Interests}

The authors have no conflict of interests to declare.

\section{References}

1 Singh A, Tetreault L, Kalsi-Ryan S, Nouri A, Fehlings MG. Global prevalence and incidence of traumatic spinal cord injury. Clin Epidemiol 2014;6:309-331

2 Lee BB, Cripps RA, Fitzharris M, Wing PC. The global map for traumatic spinal cord injury epidemiology: update 2011, global incidence rate. Spinal Cord 2014;52(02):110-116

3 Ingham SJM, Gaspar AP, Vianna PPC, Santos FPE, Masiero D, Puertas EB. Avaliação Epidemiológica dos pacientes com lesão medular atendidos no Lar Escola São Francisco. Coluna/Columna 2004;3(01):26-29

4 Botelho RV, Abgussen CMB, Machado GCFPM, , et al. Epidemiologia do trauma raquimedular cervical na zona norte da Cidade de São Paulo. Arq Bras Neurocir 2001;20(3-4):64-76

5 Salomão AF, Soares PN, Lucareli PRG, Freitas SKT, Lima FPSL, Lima MO. Estudo epidemiológico dos pacientes com traumatismo raque-medular atendidos na Clínica de Fisioterapia da UNIVAP. $X$ Latin American Meeting of Scientific Initiation and VI Latin American Meeting of Graduate Studies - University of Vale do Paraiba - 07/07/2015. Accessed in May / 2018. 757-760. Available at https://www.researchgate.net/publication/266890513.

6 Bühker MA, Lucatelli V, Amaral RB, Rockenbach CWF. Perfil clínicoweb e epidemiológico dos pacientes com lesão medular atendidos no Centro de Atendimento à Deficiência (CAD). XVI Scientific Initiation and IX Extension Exhibition. University of Passo Fundo RS. 04,05,06 / October / 2011. Accessed in May / 2018. Available at www.unicruz.edu.br/seminário/anais/anais-2011/saude.

7 Noronha JB. Levantamento epidemiológico dos casos de lesão medular espinhal traumática atendidos em unidade de reabilitação de Goiânia - Goiás [thesis]. Goiânia: Catholic University of Goiás; 2008

8 Brito LMO, Chein MBC, Marinho SC, Duarte TB. Epidemiological evaluation of victims of spinal cord injury. Rev Col Bras Cir 2011; 38(05):304-309

9 Citadini JN, Scholtão J. Souza Roger Burgo, Garanhani MR Perfil epidemiológico dos pacientes com lesão medular do Ambulatório de Fisioterapia Neurológica do Hospital Universitário Regional do Norte do Paraná Jan. 2203. Accessed in May / 2018. Available at: https://www.researchgate.net/publication/238713586

10 Custódio NRO, Carneiro MR, Feres CC, , et al. Lesão medular no Centro de Reabilitação e Readaptação Dr. Henrique Santillo (CRER-GO). Collun 2009;8(03):265-268

11 New PW, Cripps RA, Bonne L. Global maps of non-traumatic spinal cord injury epidemiology: towards a living data repository. Spinal Cord 2014;52:97-109 